\title{
Pelatihan Bahasa Prancis bagi Aktor Pariwisata Desa dan Hospitality Pengusaha Warung Makan Mahasiswa di Masa Pandemi
}

\author{
B. R. Suryo Baskoro, Subiyantoro Subiyantoro, Ali Shahab \\ Fakultas Ilmu Budaya, Universitas Gadjah Mada \\ Korespondensi: suryobaskoro@ugm.ac.id
}

\begin{abstract}
During the Covid-19 pandemic, almost all economic sectors economy were affected, included the tourism sector (area of hospitality). Welcoming a new stage of normality, the sector needs to prepare. Therefore, French Literature Program FIB provides a basic French language learning to tourism players in Ponggok village, Klaten and health awareness during the pandemy in Kuningan village, Sleman. Since business was being halted at the time, the training program was carried out with team visits to the site and the provision of basic French language training materials and modules in Ponggok village and online discussions on health awareness during the pandemy with food stall owners and students in Kuningan village. The tourism players in Ponggok village seem enthusiastic about receiving French language materials and modules and in the near future the team will come to the site to monitor its development. Meanwhile, stall owners and students in Kinanti realize that this pandemic can only be faced together by maintaining each other's health protocols.
\end{abstract}

Keywords: French; training modules; pandemic; tourism

\begin{abstract}
Abstrak
Pada masa pandemi Covid-19, hampir semua sektor ekonomi terkena dampaknya, tak terkecuali sektor pariwisata (bidang hospitality). Menyambut tahap kenormalan baru, sektor tersebut perlu mempersiapkan diri. Untuk itu, Prodi Sastra Prancis FIB memberikan pelatihan bahasa Prancis kepada para pelaku pariwisata di Desa Ponggok, Klaten dan pembekalan menghadapi new normal di kampung Kuningan, Sleman. Berhubung bisnis sedang dihentikan saat itu, program pelatihan dilaksanakan dengan kunjungan tim ke lokasi dan pemberian bahan dan modul pelatihan bahasa Prancis dasar di Desa Ponggok dan diskusi daring untuk pembekalan menghadapi pandemi dengan para pemilik warung makan dan mahasiswa di kampung Kuningan. Para pelaku pariwisata di Desa Ponggok tampak antusias menerima bahan dan modul bahasa Prancis dan dalam waktu dekat tim akan datang ke lokasi untuk memantau perkembangannya. Sementara itu, para pemilik warung dan mahasiswa di Kinanti menyadari bahwa pandemi ini hanya dapat dihadapi bersama-sama dengan saling menjaga protokol kesehatan.
\end{abstract}

Kata Kunci: bahasa Prancis; modul pelatihan; pandemi; pariwisata

\section{Pendahuluan}

Kasus pertama Covid-19 ditengarai terjadi pada 17 November 2019 dan menimpa seorang warga provinsi Hubei, China, berusia 55 tahun (The Guardian, 2020). Beberapa minggu setelah itu, barulah pemerintah China mengumumkan ditemukannya virus 
baru tersebut. Setelah diketahui, virus corona merebak ke luar daratan China dan di Eropa diidentifikasi sebanyak 20.000 orang terkonfirmasi positif serta 1.000 orang meninggal dunia. Pada 12 Maret 2020, WHO secara resmi menyatakan wabah Covid19 sebagai pandemi (WHO, 2020). Banyak pakar mengasumsikan bahwa pandemi ini merupakan siklus 100 tahunan dan banyak dibandingkan dengan pandemi influenza yang terjadi pada lebih dari tahun 1918. Keduanya mengakibatkan kontraksi besar di bidang ekonomi, hanya bedanya, pada pandemi tahun 1918 lebih banyak pekerja usia prima meninggal dunia, sedangkan pada pandemi Covid-19, orang dewasa usia kerja adalah salah satu yang paling besar peluangnya untuk bertahan hidup (Beach et al., 2020:61). Pada satu sisi, tenaga kerja usia produktif masih bertahan (hidup), tetapi dalam situasi sebagian (besar) dari mereka kehilangan pekerjaan. Di sisi lain, dalam situasi pandemi yang menyebar dengan mudah di planet yang saling terhubung ini, yang mengakibatkan biaya manusia dan ekonomi yang signifikan, kesiapsiagaan menjadi hal yang sangat penting (Burwell et al., 2020:3).

Bencana Covid-19 telah membuat seluruh dunia menderita, apalagi tidak ada seorang pun dapat memastikan kapan semua ini akan berakhir. Akhir tahun 2020? Sepertinya tidak meskipun semua orang mengharapkan begitu. Indikasi itu setidaktidaknya terlihat dari rencana Pemerintah Indonesia untuk mengadakan vaksinasi massal Covid-19 pada awal tahun 2021 (Winahyu, 2020), tentu saja setelah vaksin, yang saat ini sedang dalam tahap uji klinis ketiga, benar-benar lolos uji sehingga layak dipakai.

Di Indonesia, berdasarkan data per 18 Oktober 2020, tercatat 64.032 kasus aktif Covid-19, 285.324 kasus sembuh, dan 12.511 kasus meninggal (Satgas Penanganan Covid-19, 2020). Di samping korban manusia, pandemi ini membawa korban yang lain, yakni pingsan atau bahkan lumpuhnya hampir semua sektor usaha. Sektor usaha yang terdampak paling parah adalah sektor Akomodasi dan Makan Minum (92,47\% terdampak). Selanjutnya adalah sektor Jasa lainnya (90,90\%), serta Transportasi dan Pergudangan (90,34\%) (Badan Pusat Statistik, 2020:9; Elvira dan Hadiwinata, 2020). Dampaknya tentu saja adalah penurunan pendapatan yang sangat drastis bagi para pelaku usaha. Dilihat dari persebaran per daerah, tercatat ada empat provinsi yang paling menderita atau yang pelaku usahanya paling banyak mengalami penurunan pendapatan; berturut-turut adalah Bali (menurun 92,18\%), Daerah Istimewa Yogyakarta (89,69\%), Banten (86,91\%), dan DKI Jakarta (86,55\%) (Badan Pusat Statistik, 2020:9).

Sektor pariwisata atau hospitality adalah bagian dari sektor usaha Akomodasi dan Makan Minum dan menjadi yang paling parah menderita karena pandemi Covid-19. Hal ini tentu saja membuat prihatin semua insan pariwisata yang terlibat di dalamnya dan insan-insan yang terkait dengannya, termasuk Program Studi Sastra Prancis, FIB-UGM. Untuk itulah, Prodi Sastra Prancis membuat program pengabdian kepada masyarakat. Program yang telah disusun terdiri atas dua kegiatan, yakni (a) pengenalan bahasa Prancis dasar dan (b) pembekalan menghadapi new normal.

Adapun target kami adalah para aktor pariwisata di Desa Ponggok, Kecamatan Polanharjo, Kabupaten Klaten. Akhir-akhir ini, desa ini sedang viral terutama dengan wisata air yang dinamakan Umbul Ponggok. Kemampuan percakapan sederhana bahasa Prancis diperlukan oleh masyarakat sasaran, khususnya untuk dapat memberikan pelayanan yang lebih baik, khususnya kapada wisatawan manca negara (wisman). Menurut data tahun 2019, untuk kelompok Eropa, wisman asal Prancis, dengan total 
283.800 kunjungan, menduduki peringkat kedua setelah Inggris (397.600 kunjungan) dalam hal jumlah kunjungan ke Indonesia (Aditya dan Agmasari, 2020).

\section{Pendekatan Pelaksanaan Program}

Pendekatan yang digunakan Prodi Sastra Prancis FIB-UGM dalam pelaksanaan program pengabdian kepada masyarakat ini adalah capacity building. Konsep capacity building mengacu pada proses ketika individu, kelompok, organisasi, kelembagaan, dan masyarakat mengembangkan kemampuannya, baik secara individual maupun kolektif untuk untuk melaksanakan fungsi mereka, menyelesaikan masalah mereka, dan mencapai tujuan-tujuan mereka secara mandiri (Nugraha, 2004:3). Mengacu pada dua program di bagian pendahuluan, tujuan pelaksanaan program ialah memampukan para aktor pariwisata Desa Ponggok, Polanharjo, Klaten dalam berkomunikasi secara sederhana dengan para wisman berbahasa Prancis serta memberikan pembekalan praktis dalam masa new normal di tengah pandemi.

Setelah selesai membuat proposal kegiatan, tim melakukan kunjungan ke Desa Ponggok. Kunjungan dilakukan pada 28 Mei 2020 dan diterima oleh Kepala Desa, bapak Junaidi Mulyono. Tawaran kami untuk memberikan pembelajaran praktis bahasa Prancis dasar dan pembekalan menghadapi new normal bagi para aktor pariwisata di desanya langsung disambut antusias oleh Kepala Desa. Dua program tersebut disepakati akan dilaksanakan pada pertengahan September 2020 secara daring, khususnya melalui platform Zoom. Antusiasme tersebut kami tindaklanjuti dengan menyempurnakan materi ajar, yang sebelumnya sudah dalam tahap pembuatan rancangan materi.

Pada 2 September 2020, ketika kembali melakukan kunjungan ke Desa Ponggok untuk membuat kesepakatan waktu pelaksanaan program, bapak Yani Setiadi selaku Carik Desa memberi informasi yang mengejutkan, yakni pandemi menyebabkan para aktor pariwisata target kami sudah membubarkan diri dan mereka kembali ke pekerjaan semula, yakni bertani, berkebun, atau beralih ke bidang lain. Bahkan, menurut konfirmasi Carik Desa, pelaksanaan program secara daring tidak dimungkinkan.

Tabel 1. Tahap Pelaksanaan Program Pengabdian kepada Masyarakat

\begin{tabular}{|c|c|c|}
\hline Tahap & Waktu & Kegiatan \\
\hline \multirow{3}{*}{ Persiapan } & \multirow{2}{*}{ Mei dan Juni 2020} & Penyusunan proposal \\
\hline & & Penyusunan materi ajar \\
\hline & Juli dan Agustus 2020 & Training of trainers \\
\hline \multirow{2}{*}{$\begin{array}{l}\text { Pelaksanaan } \\
\text { program }\end{array}$} & \multirow{2}{*}{ September 2020} & $\begin{array}{l}\text { Penyerahan CD dan manual "Sinau } \\
\text { Basa Prancis neng nDesaku" }\end{array}$ \\
\hline & & $\begin{array}{l}\text { Pelaksanaan diskusi daring } \\
\text { "Hospitality di masa pandemi" }\end{array}$ \\
\hline \multirow{2}{*}{$\begin{array}{l}\text { Evaluasi dan } \\
\text { pelaporan }\end{array}$} & \multirow{2}{*}{ Oktober 2020} & Evaluasi \\
\hline & & Pembuatan laporan dan artikel kegiatan \\
\hline
\end{tabular}

Sumber: Tim PkM 
Meskipun sangat disayangkan, update dari Carik Desa tersebut membuat kami melakukan penyesuaian. Kegiatan pembelajaran bahasa Prancis dasar tetap akan kami laksanakan bagi aktor pariwisata Desa Ponggok, sementara masyarakat sasaran untuk kegiatan pembekalan menghadapi new normal kami alihkan ke para pemilik warung dan mahasiswa di kampung Kuningan, Karangmalang, Caturtunggal, Depok, Sleman. Dengan penyesuaian itu maka time line program dan rincian kegiatan pengabdian masyarakat tahun ini menjadi seperti yang tertampil pada tabel 1 .

Untuk mengetahui lebih banyak tentang Desa Ponggok dan Kampung Kuningan, di bawah ini ditampilkan terlebih dahulu profil kedua lokasi yang menjadi target pengabdian masyarakat oleh Prodi Sastra Prancis FIB-UGM tahun 2020.

\section{Profil Desa Ponggok}

Desa Ponggok berlokasi di Kecamatan Polanharjo, Kabupaten Klaten. Awal tahun 2000, Ponggok merupakan desa miskin dengan pendapatan hanya Rp80.000.000,00/ tahun. Berkat kiprah sang lurah, Junaedhi Mulyono, desa menjelma menjadi terkaya, dengan wisata mata air sebagai andalan penghasilannya. Junaedhi menggandeng pihak akademika dan para ahli untuk melihat dan berusaha memaksimalkan potensi alam
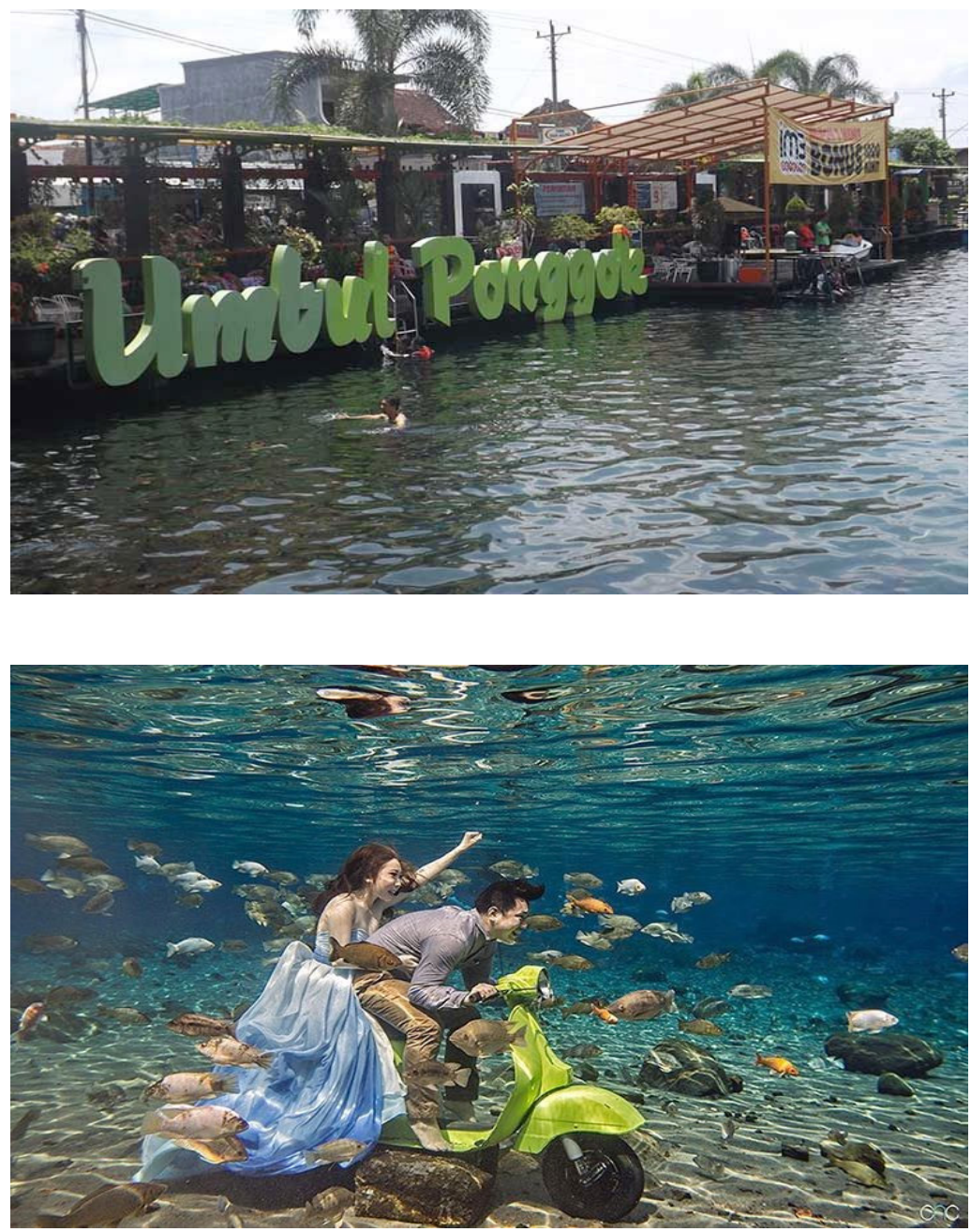

Gambar 1. Umbul Ponggok. Sumber: https://www. kompasiana.com/har ison/5c0e3b0cc112fe 6a424ae9d5/kepaladesa-di-yogyakartatirulah-desaponggok? page=all

Gambar 2. Wisata air di Umbul Ponggok. Sumber: https:// gpswisataindonesia. info/2018/12/desawisata-air-ponggokpolanharjo-klatenjawa-tengah/ 
desa, yang salah satunya adalah air yang cukup melimpah yang mucul dari mata air hingga mewujudkan wisata bawah air Umbul Ponggok yang kemudian menjadi salah satu ikon wisata Kabupaten Klaten. Desa Ponggok juga berkembang pesat dengan penghasilan desa hampir mencapai Rp16 miliar/tahunnya (Hananto, 2019). Desa yang berpenduduk 2.300 orang menjadi desa terkaya karena memiliki APBDes sebesar Rp4,2 miliar pada tahun 2018 lalu, Pendapatan Asli Daerah (PAD) desa mencapai Rp1,7 miliar, dan pendapatan beberapa tempat wisata serta unit bisnis yang dikelola BUMDes pada tahun 2018 mencapai Rp16 miliar (Nurohmah, 2017).

\section{Profil Kampung Kuningan}

Kampung Kuningan merupakan bagian dari Padukuhan Karangmalang, Kelurahan Caturtunggal, Kecamatan Depok, Kabupaten Sleman. Desa Caturtunggal memiliki luas wilayah $11.070 .000 \mathrm{~m}^{2}$ atau 889.7480 ha dan didiami oleh 61.606 jiwa (data tahun 2012). Kekhasan desa ini adalah menjadi lokasi 23 perguruan tinggi, negeri dan swasta, di samping banyak sekolah, dari SD hingga SMA. Tidak heran bahwa hampir seperempat

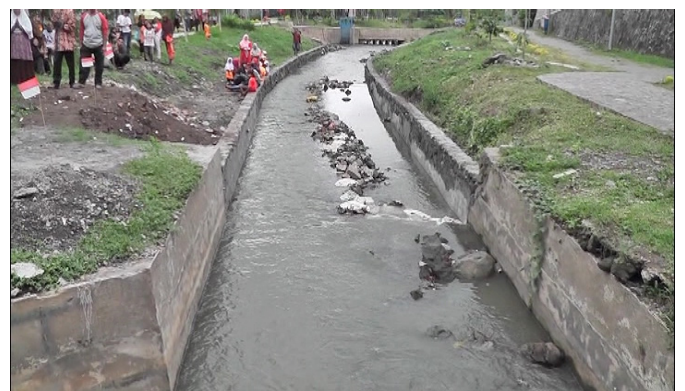

Gambar 3. Budaya Merti Kali mBelik Kuningan. Sumber: https://jogjatv.co.id/ news/read/merti-kali-mbelik-kuningan total penduduknya adalah para mahasiswa yang tinggal (untuk sementara) di lokasi indekos dan penginapan. Desa ini juga menjadi lokasi bagi tiga rumah sakit besar, negeri, dan swasta (Wikipedia.org).

\section{Pelaksanaan Program}

Sesuai dengan penyesuaian yang telah dijelaskan sebelumnya, program pengabdian kepada masyarakat yang telah dilaksanakan di lapangan oleh Prodi Sastra Prancis FIBUGM diuraikan berikut ini.

\section{Pengenalan Bahasa Prancis Dasar}

Sebagaimana telah dijelaskan sebelumnya, berhubung Carik Desa Ponggok mengonfirmasi (pada kunjungan yang dilakukan oleh tim PkM pada 2 September 2020) bahwa semua pelaku pariwisata di desanya membubarkan diri akibat pandemi, bahkan pembelajaran daring pun dikonfirmasi tidak dimungkinkan, maka kami melaksanakan program dengan menyerahkan sejumlah 23 Manual Pelajaran Bahasa Prancis Dasar dan CD. Berikut sampul manual "Sinau Basa Prancis neng nDesaku".

Buku ini memuat tanya-jawab dalam bahasa Prancis dengan dialog-dialog yang sederhana. Kemampuan menanyakan hal-hal kecil (seperti kata-kata sapaan dan kata-kata tanya siapa, di mana, kapan) dan kemampuan menjawab pertanyaan dengan kalimatkalimat singkat dalam bahasa Prancis diyakini akan meningkatkan ketertarikan dan perhatian wisman berbahasa Prancis yang berkunjung. Menurut data yang diterbitkan oleh Organisation internationale de la Francophonie (2019: 32), jumlah penutur bahasa Prancis di seluruh dunia, yang disebut francophonie, adalah 300 juta orang, yang 
tersebar di 42 negara, termasuk Prancis. Penutur bahasa Prancis di 42 negara itu terbagi dalam empat status, yakni yang (a) lahir dalam lingkungan bahasa Prancis (selain Prancis, ada juga, misalnya CanadaQuébec dan Monaco), (b) menggunakan bahasa Prancis sebagai bahasa resmi (misalnya Burkina Faso, Senegal, Togo), (c) menggunakan bahasa Prancis sebagai salah satu bahasa mereka (seperti Maroko, Tunisia, Aljazair), dan (d) menggunakan

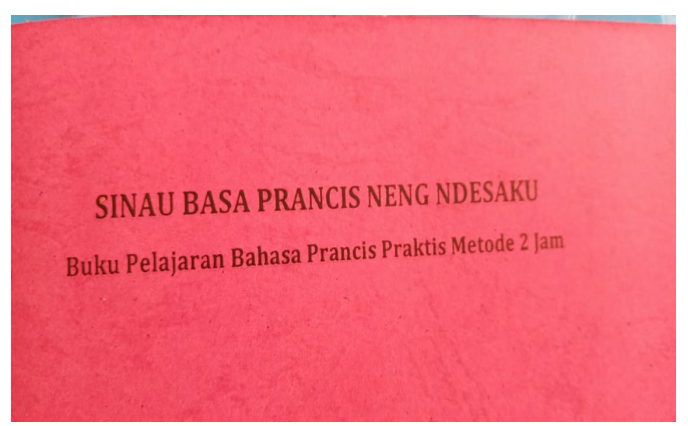

Gambar 4. Buku pelajaran bahasa Prancis dasar "Sinau Basa Prancis neng nDesaku". Sumber: Dokumentasi Tim PkM bahasa Prancis sebagai salah satu bahasa resmi (misalnya Swiss, Belgia, Luxemburg, Vanuatu). Sebagaimana telah disebutkan sebelumnya, wisman asal Prancis menempati urutan kedua dari Eropa (setelah Inggris) yang paling banyak mengunjungi nusantara. Angka itu akan bertambah jika yang dihitung bukan asal negaranya, melainkan bahasa yang digunakan oleh wisman itu. Situasi tersebut menjadikan penguasaan dasar-dasar bahasa Prancis menjadi unsur yang signifikan dalam rangka meningkatkan jumlah kunjungan, khususnya wisman, ke Desa Ponggok, Klaten.

\section{Pembekalan Menghadapi New Normal}

Seturut dengan dengan penyesuaian program yang telah dijelaskan sebelumnya, program Pembekalan menghadapi new normal kami laksanakan dengan mengubah target audience mejadi para pemilik warung makan dan mahasiswa (indekosan) di kampung Kuningan, Karangmalang, Caturtunggal, Depok, Sleman. Program ini kami laksanakan secara daring pada 30 September 2020 dalam bentuk diskusi dengan pemantik seorang narasumber. Di bawah ini adalah flyer program tersebut.

Program pembekalan menghadapi new normal kami wujudkan dalam webinar dengan judul "Hospitality di Masa Pandemi". Pemilik warung makan dan mahasiswa

Webinar Pengabdian

Sastra Prancis Universitas Gadjah Mada Yogyakarta

\section{Hospitality di Masa Pandemi}

Rabu, 30 September 2020 20:00 WIB

(1) Zoom meeting

bit.ly/hospitalityprancis

Narasumber

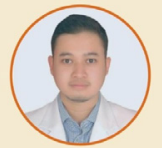

dr. Hanif Shahab

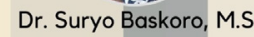

Gambar 5. Flyer webinar "Hospitality di masa pandemi”. Sumber: Tim PkM (indekos) adalah dua pihak yang terlibat juga dalam sektor hospitality. Webinar ini diikuti oleh 72 peserta, yang terdiri atas para pemilik warung di kampung Kuningan, mahasiswa, dan tim pengabdian Prodi Sastra Prancis FIB-UGM. Narasumber atau pemantik diskusi pada webinar ini adalah dr. Hanif Shahab dari Semarang. Di bawah ini adalah screenshots kegiatan tersebut.

Pada webinar tersebut didiskusikan beberapa hal penting yang perlu diketahui, khususnya oleh para pelaku sektor hospitality pada masa pandemi. Di samping anjuran-anjuran resmi pemerintah perihal protokol kesehatan yang standar, seperti 


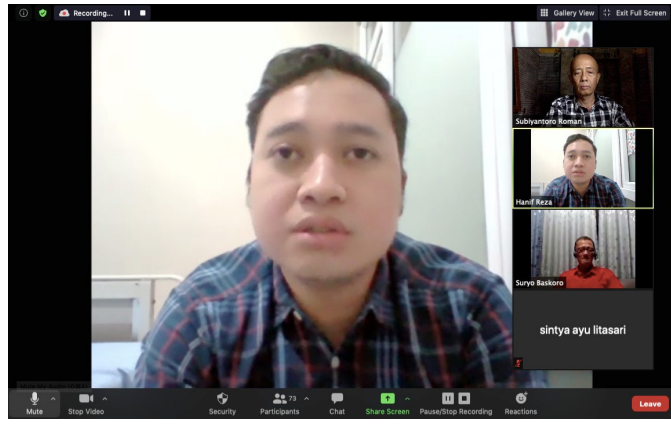

Gambar 6. Narasumber, dr. Hanif Shahab. Sumber: Dokumentasi Tim PkM

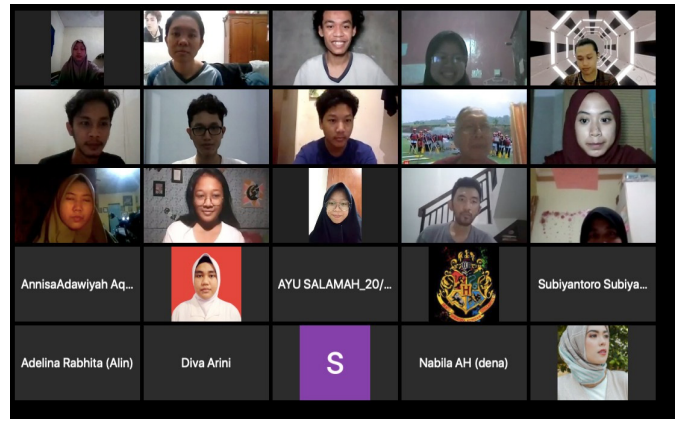

Gambar 7. Sebagian peserta Webinar. Sumber: Dokumentasi Tim PkM

memakai masker, mencuci tangan, dan menjaga jarak, narasumber mengangkat juga beberapa hal khusus yang perlu diperhatikan oleh para pemilik warung dan konsumen (yang dalam hal ini adalah mahasiswa), seperti tidak memakai perhiasan dan tidak memakai rok (bagi wanita). Diskusi dengan nara sumber menghasilkan awareness bersama, yakni bahwa ketaatan pada protokol kesehatan harus dimulai dari diri kita sendiri.

\section{Refleksi Capaian Program}

Ketidakberhasilan pembelajaran bahasa Prancis dasar secara daring kepada para aktor pariwisata di Desa Ponggok, Klaten merupakan cermin dari betapa dahsyatnya dampak yang ditimbulkan oleh pandemi Covid-19. Pandemi ini telah membuat sektor pariwisata, khususnya wisata air di Desa Ponggok menjadi lumpuh total. Karena tidak ada pengunjung, aktivitas menjadi berhenti total. Akibatnya, para pekerjanya kehilangan pekerjaan dan untuk dapat melanjutkan kehidupan, mereka kembali menekuni kegiatan mereka sebelumnya, yakni bertani atau bercocok tanam, atau menekuni jenis pekerjaan lain. Alhasil, karena target audience-nya sudah membubarkan diri, pembelajaran daring pun, apalagi luring, tidak dapat terlaksana.

Ketidakberhasilan itu tentu saja menjadi tantangan tersendiri, tetapi bukan bagi Prodi Sastra Prancis FIB-UGM secara khusus, melainkan tantangan bersama dan tantangan untuk menghidupkan kembali sektor hospitality hanya dapat kita jawab dengan kerja keras yang melibatkan semua pihak: pemerintah, pihak swasta, dan masyarakat pada umumnya.

\section{Penutup}

Ketidakberhasilan pemberian pembelajaran bahasa Prancis dasar secara daring, meskipun program kedua (pembekalan menuju era new normal) berhasil dengan baik, menjadikan tingkat ketercapaian kegiatan PkM Prodi Sastra Prancis FIB-UGM barulah sekitar $80 \%$. Sambil bersama-sama berharap agar pandemi Covid-19 segera berakhir, program pembelajaran bahasa Prancis dasar bagi kelompok masyarakat yang bergerak di sektor hospitality merupakan program yang baik untuk dipertahankan dan dilanjutkan. Program 
ini diyakini akan mampu menarik kunjungan wisman lebih banyak lagi, khususnya wisman yang berbahasa Prancis. Selain kemampuan berkomunikasi dasar bahasa Prancis, Program Studi Bahasa Prancis merekomendasikan objek-objek wisata untuk melengkapi situs web atau media-media sosial yang mereka gunakan, termasuk brosur atau fyers, dengan keterangan-keterangan pendek dalam bahasa Prancis.

\section{Daftar Pustaka}

Aditya, N.R. dan S. Agmasari. (2020). "5 Negara Asal Wisatawan Mancanegara yang Paling Banyak Berkunjung ke Indonesia". Diunduh dari https://travel.kompas.com/ read/2020/02/05/200500527/5-negara-asal-wisatawan-mancanegara-yang-palingbanyak-berkunjung-ke?page=all.

Badan Pusat Statistik. (2020). Analisis Hasil Survei Dampak Covid-19 Terhadap Pelaku Usaha. Diunduh dari https:/www.bps.go.id/publication/2020/09/15/9efe2fbda7d 674c09ffd0978/analisis-hasil-survei-dampak-covid-19-terhadap-pelaku-usaha.html.

Beach Brian, Clay, Karen dan Saavedra, Martin H. (2020). The 1918 Influenza Pandemic And Its Lessons For Covid-19. Working Paper 27673 National Bureau Of Economic Research. England: Cambridge. Diunduh dari http://www.nber.org/papers/w27673.

Burwell, Sylvia Mathews dan Townsend, Frances Fragos (Chairs); Bollyky, Thomas J. and Patrick, Stewart M. (Project Directors). (2020). Improving Pandemic Preparedness: Lessons From COVID-19. Independent Task Force Report No. 78. USA: the Council on Foreign Relations ${ }^{\oplus}$, Inc. Diunduh dari https://www.cfr.org/report/pandemicpreparedness-lessons-COVID-19/.

Elvira, Nathasya dan Hadiwinata, Thomas. (2020). Inilah Sektor Usaha yang Mengalami Dampak Paling Buruk dari Pandemi. Diunduh dari https://insight.kontan.co.id/ news/inilah-sektor-usaha-yang-mengalami-dampak-paling-buruk-dari-pandemi.

Hananto, Akhyari. (2019). Dari Wisata dan Ikan, Desa yang Dulunya Termiskin ini Kini Menjadi Desa Terkaya. Diunduh dari https://www.goodnewsfromindonesia. id/2019/06/11/dari-wisata-dan-ikan-desa-yang-dulunya-termiskin-ini-kinimenjadi-desa-terkaya.

Nugraha. (2004). Pengembangan Kapasitas (Capacity Building) dalam Mendukung Pelaksanaan Otonomi Daerah. Dalam Jurnal Ilmu Administrasi Vol 1, No 3 (2004). Diunduh dari http://jia.stialanbandung.ac.id/index.php/jia/article/view/334/308.

Nurohmah. Gina. (2017). BUMDes Tirta Mandiri Desa Ponggok, Ratusan Warganya Ikut Memiliki. Diunduh dari https://binadesa.org/bumdes-tirta-mandiri-desaponggok-ratusan-warganya-ikut memiliki/\#:- :text=Desa $\% 20$ Ponggok $\% 20$ pun $\% 20$ terpilih\%20sebagai,3\%20miliar\%20dari\%20tempat\%20tersebut.

Organisation internationale de la Francophonie. (2019). La langue française dans le monde:

2015-2018. Paris: Gallimard. Diunduh dari https://www.francophonie.org/sites/default/ files/2020-02/Edition\%202019\%20La\%20langue\%20francaise $\% 20$ dans $\% 20$ le\%20monde_VF\%202020\%20.pdf.

Satuan Tugas Penanganan Covid-19. (2020). Analisis Data Covid-19 Indonesia, Update per 18

Oktober 2020. Diunduh dari https://covid19.go.id/p/berita/analisis-data-covid-19indonesia-update-18-oktober-2020. 
The Guardian. (2020). First Covid-19 case happened in November, China government records

show - report. Diunduh dari https://www.euro.who.int/en/health-topics/healthemergencies/coronavirus-covid-19/news/news/2020/3/who-announces-covid-19outbreak-a-pandemic.

Wikipedia. Caturtunggal, Depok, Sleman. Diunduh dari https://id.wikipedia.org/wiki/ Caturtunggal,_Depok,_Sleman.

WHO. (2020). WHO announces COVID-19 outbreak a pandemic. Diunduh dari https:/www.euro.who.int/en/health-topics/health-emergencies/coronaviruscovid-19/news/news/2020/3/who-announces-covid-19-outbreak-a-pandemic.

Winahyu, Atikah Ishmah. (2020). Target Vaksinasi Massal Covid-19 Awal 2021. Diunduh dari https://mediaindonesia.com/read/detail/341894-target-vaksinasimassal-covid-19-awal-2021. 